\title{
Sosial Media Instagram Untuk Promosi Usaha Perjalanan Wisata di Banjar Puseh Batubulan Kangin Gianyar Bali
}

\author{
Bagus Made Sabda Nirmala ${ }^{1 *}$, Made Liandana ${ }^{2}$, Pande Putu Gede Putra Pertama ${ }^{3}$ \\ ${ }^{1,2}$ Program Studi Teknologi Informasi, Institut Teknologi dan Bisnis (ITB) STIKOM Bali \\ ${ }^{3}$ Program Studi Sistem Informasi, Institut Teknologi dan Bisnis (ITB) STIKOM Bali \\ ${ }^{1}$ sabda@stikom-bali.ac.id, ${ }^{2}$ liandana@ $@$ stikom-bali.ac.id, ${ }^{3}$ putrapertama@ stikom-bali.ac.id
}

\begin{abstract}
Currently, technology is a basic requirement if a business wants to develop. Technology is no longer just a substitute for a business. Without technological support, a business will find it difficult to develop and generate profits. Not only in business processes, the promotion or marketing of business also requires technology. In this case, social media is a technology-based sharing platform that can help MSME players market their products. one of them is this service partner, UMKM Bali Daily Trip \& Tour, which markets tour tour products. Products marketed are mainly the Nusa Penida Day Tour, which is a day tour in Nusa Penida. The development and improvement of a Bali Daily Trip \& Tour UMKM business is very dependent on the use of existing technology, especially promotion using social media. UMKM actors must be able to take advantage of social media as a gathering place for their potential customers. One of the popular social media is Instagram. Instagram is currently an efficient promotional tool to get consumers, especially the youth market, who like holidays with tourist destinations in Bali. This community service aims to provide counseling on the use of social media as a media for promotion of tour packages for MSMEs Bali Daily Trip \& Tour in Banjar Puseh, Batubulan Kangin, Gianyar Regency, Bali. Based on the results of the service activities that have been carried out, the participants have been able to understand the Insight feature which functions to determine the effectiveness of posted content and partners have also been able to determine a good posting schedule so that it can streamline the marketing process through social media.
\end{abstract}

Keywords : UMKM Bali Daily Trip \& Tour, promotion, Instagram

\begin{abstract}
Abstrak
Saat ini, teknologi menjadi kebutuhan pokok jika suatu usaha ingin berkembang. Teknologi tidak lagi hanya menjadi substitusi dari suatu bisnis. Tanpa adanya dukungan teknologi, sebuah usaha akan sulit berkembang dan menghasilkan profit. Tidak hanya pada proses bisnis, bagian promosi atau memasarkan bisnis juga membutuhkan teknologi. Dalam hal ini sosial media merupakan platform berbagi berbasiskan teknologi yang dapat membantu para pelaku UMKM memasarkan produk mereka. Sosial media Instagram dapat memberikan manfaat dalam membantu meningkatkan awareness sebuah usaha dan juga dapat membantu promosi secara digital yang lebih efisien. Hal ini dikarenakan berbagi melalui media sosial Instagram hingga saat ini masih bebas biaya. Selain itu pemanfaatan instagram yang tepat, dapat membantu jangkauan pengguna yang lebih banyak. Salah satunya mitra dampingan pengabdian ini adalah usaha perjalanan wisata UMKM Bali Daily Trip \& Tour yang memasarkan produk-produk tour wisata. Produk yang dipasarkan terutama nusa penida day tour, yaitu tour sehari di pulau Nusa Penida. Pengembangan dan peningkatan suatu usaha UMKM Bali Daily Trip \& Tour sangat bergantung dengan pemanfaatan teknologi yang ada, khususnya promosi menggunakan sosial media. Para pelaku usaha perjalanan wisata, harus mampu memanfaatkan sosial media sebagai tempat berkumpulnya para calon konsumen mereka. Salah satu sosial media yang populer adalah instagram. Instagram saat ini merupakan sarana promosi yang efisien untuk mendapatkan konsumen terutama pasar anak muda yang menyukai liburan dengan tujuan wisata di Bali. Pengabdian Masyarakat ini bertujuan untuk memberikan penyuluhan pemanfaatan sosial media sebagai media promosi paket wisata untuk usaha perjalanan wisata UMKM Bali Daily Trip \& Tour di Banjar Puseh, Batubulan kangin kabupaten Gianyar, Bali. Berdasarkan hasil kegiatan pengabdian yang telah dilaksanakan peserta telah mampu memahami fitur
\end{abstract}


Insight yang berfungsi untuk mengetahui keefektikan dari konten yang di-posting dan mitra juga telah mampu menentukan jadwal posting yang baik sehingga dapat mengefisienkan proses marketing melalui sosial media.

Kata Kunci: Usaha Perjalanan Wisata, promosi, sosial media instagram

*Penulis Korespondensi : Bagus Made Sabda Nirmala

\section{PENDAHULUAN}

Perkembangan teknologi seperti industri 4.0 saat ini sangat pesat, terutama teknologi informasi dari sebuah pesan percakapan yang harus dikirimkan melalui surat sekarang sudah berevolusi hanya dengan menggunakan aplikasi chat untuk bertukar pesan, dengan bantuan teknologi Internet. Internet merupakan backbone pertukaran informasi tanpa batas di seluruh dunia. Internet mampu menyediakan resource informasi yang tidak terbatas (Meeker, 2018). Melalui internet, seseorang dapat berkomunikasi secara global dan tidak terbatas tempat, zona waktu, dan serta birokrasi atau protokoler. Internet dapat memberikan berbagai macam informasi terbaru yang kita butuhkan. Internet sudah menjadi kebutuhan bagi masyarakat khususnya bagi masyarakat di daerah perkotaan. Masyarakat perkotaan khususnya anak muda daerah perkotaan sudah mengenal internet sejak kecil atau yang dikenal dengan istilah masyarakat digital native (Kirschner and De Bruyckere, 2017). Masyarakat digital native terbiasa menggunakan perangkat elektronik seperti komputer, laptop, maupun smart phone sejak kecil.

Perkembangan teknologi informasi membuat internet semakin mudah untuk di akses. Dahulu internet hanya dapat diakses dengan menggunakan komputer namun saat ini internet dapat diakses dengan menggunakan smartphone di mana saja dan kapan saja. Pemanfaatan internet secara baik dan benar akan memberikan dampak positif. Pada Usaha Mikro Kecil dan Menengah (UMKM) saat ini juga harus memikirkan pemanfaatan teknologi informasi berupa sosial media dalam hal membantu mengenalkan produk yang dihasilkan (Suci, 2017). Kementerian Komunikasi dan Informatika mengungkapkan $95 \%$ dari 63 juta orang pengguna internet adalah pengakses media sosial (Fauzi, 2018). UMKM yang masih menggunakan cara konvensional dalam memasarkan produk atau jasanya tentunya harus dapat memanfaat peluang ini dengan memanfaatkan pengguna media sosial tersebut. Di sisi lain, Instagram merupakan aplikasi berbasis mobile yang banyak digunakan oleh anak muda untuk mengakses informasi termasuk konsumsi berita dan juga mencari layanan yang dibutuhkan (Leaver, T., Highfield, T., \& Abidin, 2020). Media sosial juga merupakan salah satu pemanfaatan teknologi informasi yang paling mudah dimanfaatkan oleh para pelaku UMKM. Sosial media instagram dapat memberikan manfaat dalam meningkatkan awareness sebuah usaha dan juga dapat membantu promosi secara digital yang lebih efisien. Hal ini dikarenakan sharing melalui media sosial instagram hingga saat ini masih bebas biaya. Selain itu pemanfaatan Instagram yang tepat, dapat membantu jangkauan pengguna yang lebih banyak. Di sisi lain, Usaha Perjalanan Wisata UMKM Bali Daily Trip and Tour di Banjar Puseh Desa BatuBulan Kangin, Gianyar, saat ini masih kurang memanfaatkan sosial media instagram untuk membantu pemasaran digital.
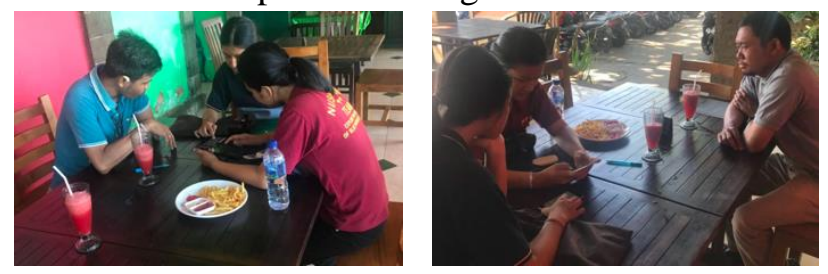

Gambar 1. Tim UMKM Bali Daily Trip and Tours Bersama Tim Pengabdian Masyarakat Saat Dijelaskan Tentang Media Sosial Instagram

Saat sebelum kegiatan pengabdian dilakukan, usaha perjalanan Wisata UMKM Bali Daily Trip and Tours sudah memiliki akun Instagram dengan nama sebelumnya adalah@balidailytrip. Sedangkan saat ini akun tersebut telah berganti nama yaitu@visitpenida, dikarenakan mitra dampingan ingin lebih fokus pada paket tour nusa penida saja. Selain itu, nusa penida merupakan destinasi wisata yang saat ini paling diminati wisatawan domestik maupun mancanegara. Pengelolaan akun instagram sebelumnya tidak terlalu aktif dalam mengunggah tentang nusa penida. Sosial media dari 
UMKM ini saat sebelum dilakukan pengabdian masih berupa akun personal bukan akun bisnis di Instagram. Mitra pengabdian yang berasal dari usaha perjalanan wisata UMKM Bali Daily Trip and Tours ini diharapkan dapat membuka pemahaman bahwa sosial media sudah menjadi hal yang mudah dan wajib digunakan oleh para pelaku UMKM yang ada di Bali. Program Pengabdian masyarakat ini, diharapkan mampu memberikan pemahaman dan pemanfaatan teknologi informasi khususnya sosial media Instagram. Sehingga dengan penyuluhan penggunaan sosial media Instagram, mampu memberikan pemahaman kepada UMKM dalam mempromosikan produk wisata yang dimiliki dengan instagram dapat meningkatkan promosi paket perjalanan wisata mitra dampingan.

Usaha perjalanan wisata UMKM Bali Daily Trip and Tours ini terdiri dari dua orang yaitu Ni Kadek Uniantari dan Oktavia Purnama seperti dapat dilihat pada Gambar 1 saat mitra dampingan dijelaskan tentang media sosial instagram. Gambar 2 menunjukkan struktur organisasi mitra dampingan. Selain itu pada gambar 2 juga terdapat dokumentasi kegiatan tour nusa penida dari mitra dampingan. Tim UMKM Bali Daily Trip lebih sering mengorganisir trip dari meeting point mereka di Sanur. Promosi yang dilakukan juga lebih kepada sistem bekerjasama dengan agen yang memberikan tamu kepada mitra dampingan ini. Pengabdian ini bertujuan untuk mengetahui pemahaman mitra dampingan dalam mempelajari media sosial instagram untuk promosi digital. Selain itu juga, bertujuan agar mitra memahami strategi post konten hingga memahami insight instagram.
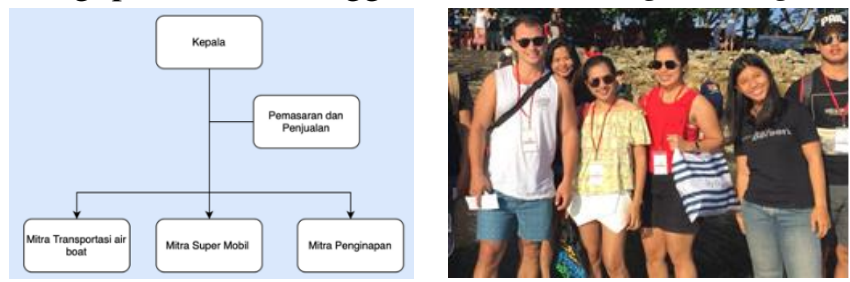

Gambar 2. Struktur organisasi UMKM Mitra Dampingan dan Foto Saat Tour Bersama Tamu

\section{METODE}

Alur pelaksanaan kegiatan pengabdian masyarakat yang telah dilaksanakan ditunjukkan pada Gambar 3 . Kegiatan pengabdian dilakukan dengan metode sosialisasi berupa presentasi dengan memberi kesempatan kepada mitra untuk mencoba hal-hal yang telah diinformasikan kepada mitra. Kegiatan pengabdian ini dilakukan selama 6 bulan: (1) Kegiatan diawali dengan proses perencanaan, mengingat kondisi masih pandemi sehingga ada kegiatan yang dilaksanakan secara daring sehingga teknis kegiatan perlu direncanakan secara baik, mulai dari keperluan perangkat lunak dan perangkat keras yang diperlukan. (2) Sosialisasi kegiatan dilakukan secara tatap maya, pada pertemuan ini dibahas pengenai teknis pelaksanaan pengabdian. (3) Pelaksanaan kegiatan pengabdian masyarakat ini dilaksanakan secara tatap muka (sebelum pandemi) dan tatap maya (saat pandemi) dengan menggunakan aplikasi zoom. (4)

Evaluasi kegiatan pengabdian ini dilakukan dengan melihat insight dari account Instagram yang digunakan dan dilihat juga dari kemampuan mitra dalam memahami materi yang diberikan.

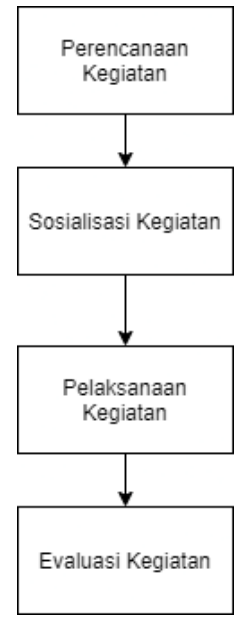

Gambar 3. Alur Pelaksanaan Kegiatan

\section{HASIL DAN PEMBAHASAN}

\section{A. Pelaksanaan Kegiatan}

Kegiatan pengabdian masyarakat ini dilaksanakan saat sebelum dan masih di masa pandemic.Terdapat kegiatan yang pelaksanaannya tidak dapat dilaksanakan secara tatap muka, untuk itu kegiatan ini dilakukan dengan menggunakan aplikasi Zoom. Peserta dari mitra yang hadir dalam kegiatan ini ada dua orang, seperti ditunjukkan pada Gambar 4. Pelaksanaan secara online melalui aplikasi zoom bertujuan untuk menjelaskan tentang bagaimana memulia beriklan di Instagram 
melalui aplikasi Zoom Meeting dan juga memahami insight post pada Instagram. Materi yang diberikan kepada mitra meliputi.

1. Memahami insight post dari akun Instagram mitra

2. Memahami dan workshop Instagram ads (iklan pada Instagram)

3. Memahami jam post yang tepat di Instagram

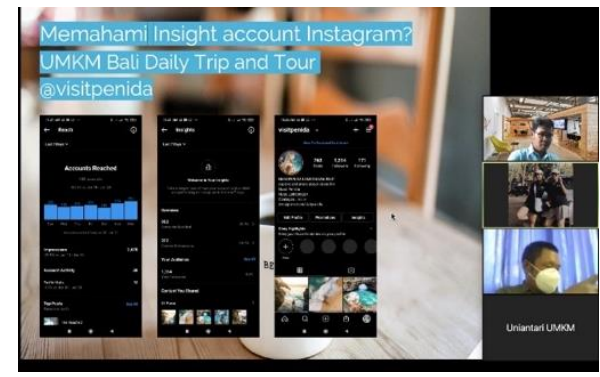

Gambar 4. Pelaksanaan melalui aplikasi Zoom

Insight post merupakan performa dalam bentuk kuantitatif yang menunjukkan seberapa efektif performa dari post pada akun Instagram mitra (Fatanti and Suyadnya, 2015). Sedangkan pada pelaksanana kegiatan beriklan di Instagram dibagikan bagaimana teknik terbaik untuk beriklan di Instagram, dimulai dari pemilihan custom audience. Custom audience merupakan pengaturan audience yang dapat dilakukan untuk menentukan target iklan dari Instagram ads (Latiff and Safiee, 2015). Pengaturan custom audience dapat dilihat pada gambar 5 .

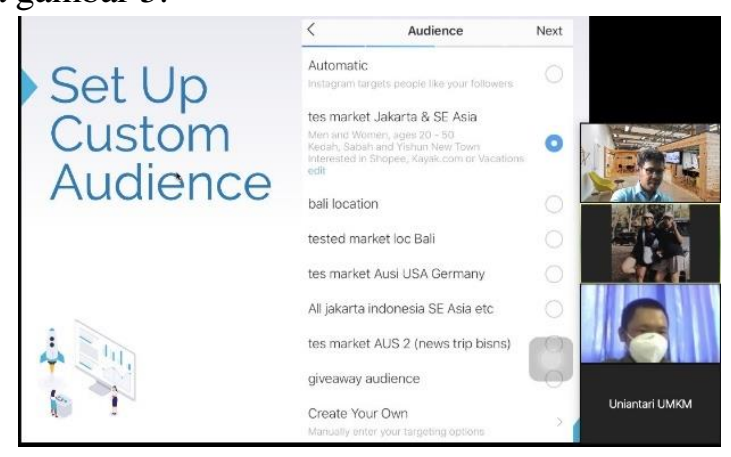

Gambar 5. Mengatur Custom Audience Untuk Instagram Ads

Setelah itu, dilanjutkan dengan mengatur budget Instagram ads dan me-review kembali ad Instagram untuk selanjut dipublikasikan di Instagram feed. Setelah Instagram ad berjalan, mitra dapat mengecek insight dari
Instagram ad yagn sudah di post tersebut. Hal ini bertujuan untuk mengecek performa post Instagram ads yang sudah dilakukan sebelum nya. Gambar 6 menunjukkan materi kegiatan terkait pengecekan insight Instagram post.

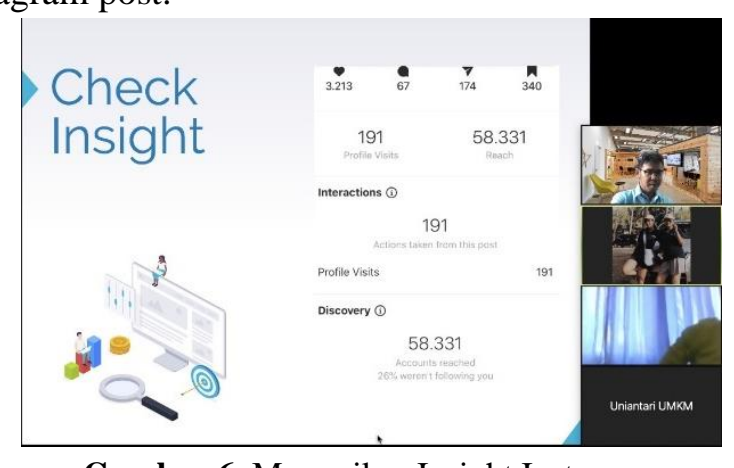

Gambar 6. Memeriksa Insight Instagram Feed Post

\section{B. Hasil Evaluasi}

Dari kegiatan pengabdian ini, yang memanfaatkan sosial media sebagai promosi, mitra telah berhasil mencoba untuk melakukan Instagram post pada media sosial Instagram dan berhasil mencoba fitur instagram $a d s$. Selain itu juga, telah dilakukan pendataan terhadap insight dari post yang telah dilakukan pada akun Instagram mitra. Terdapat lima buah posting-an dengan konten atau foto seperti yang disebutkan pada Tabel 1.

Tabel 1. Foto yang di-posting dan di data insight-nya

\begin{tabular}{|c|l|}
\hline $\begin{array}{c}\text { Post } \\
\text { ke }\end{array}$ & \multicolumn{1}{|c|}{ Konten/Foto } \\
\hline 1 & Tembeling natural spring \\
\hline 2 & Pemandangan Kelingking Beach dari tebing Kelingking \\
\hline 3 & Rumah pohon atuh \\
\hline 4 & Tebing Kelingking Cliff \\
\hline 5 & Aktivitas swing dengan pemandangan diamond beach \\
\hline
\end{tabular}

Ada 2 hal penting yang perlu diperhatikan dalam melihat insight post pada Instagram, yaitu reach dan impression. Reach merupakan bagian yang menunjukkan data seberapa banyak unique user Instagram yang melihat sebuah post dari akun yang dikelola. Sedangkan impression adalah jumlah total berapa kali pengguna melihat post dari akun yang dikelola. Gambar 6.a menunjukkan insight dari posting-an pertama dengan hasil reach mencapai 280 dan impression sebanyak 297. 
Posting-an kedua menunjukkan jumah reach mencapai 196 dan impression sejumlah 202 seperti pada grafik yang Gambar 6.b. Post ketiga diperoleh reach mencapai 540 dan impression sebanyak 555 seperti pada Gambar 6.c. Pada posting-an keempat menghasilkan reach sebanyak 109 dan impression sebanyak 116, sedangkan posting-an kelima dihasilkan reach 139 dan impression sebanyak 147 seperti ditunjukkan pada grafik Gambar 6.d dan 6.e.

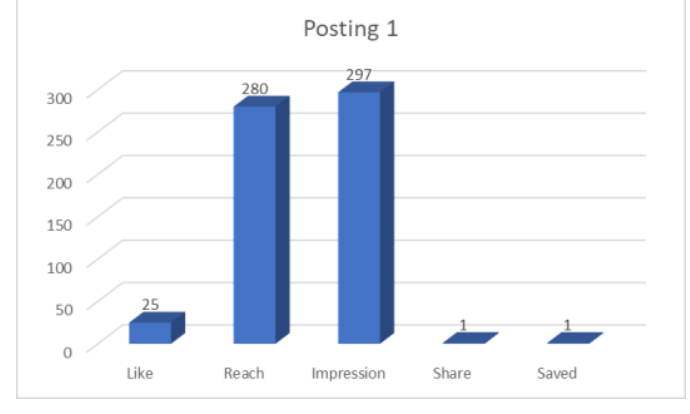

a. Insight Posting 1

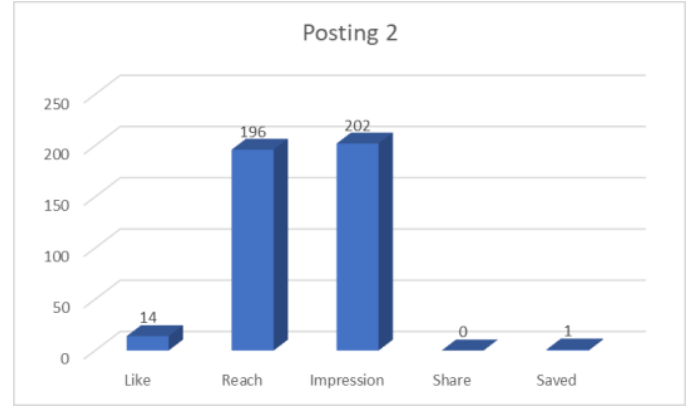

b. Insight Posting 2

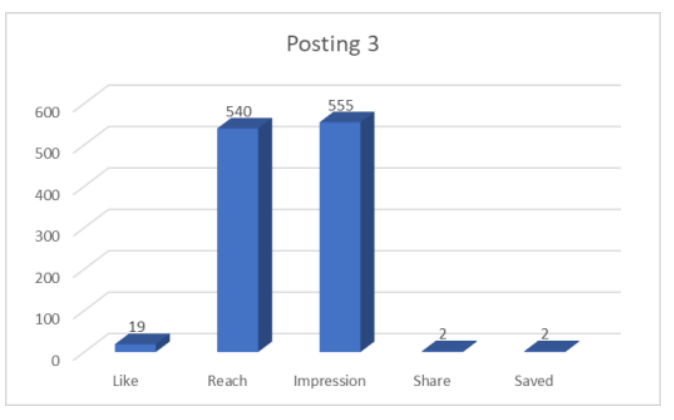

c. Insight Posting 3

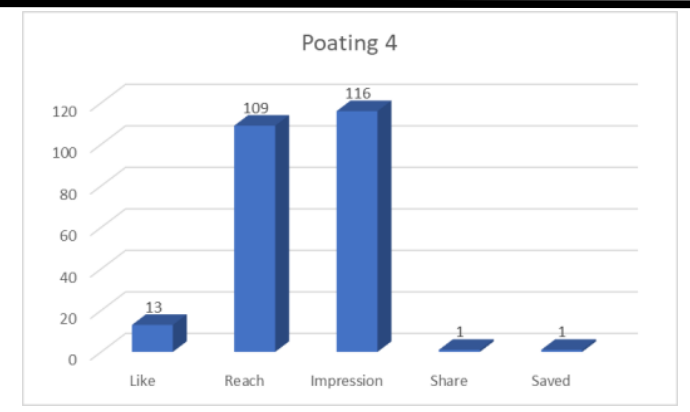

d. Insight Posting 4

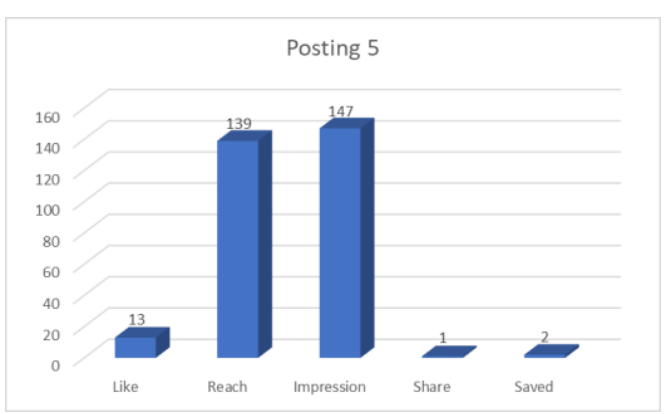

e. Insight Posting 5

Gambar 6. Hasil Insight Instagram Feed Post

Dari hasil insight ini diperoleh bahwa, insight akan semakin besar jika post yang dilakukan di jam yang tepat dan kualitas fotografi yang baik. Hal ini akan meningkatkan engagement pengguna Instagram, lalu akan menaikkan exposure yang memungkinkan post tersebut muncul di menu explore Instagram (Rietveld et al., 2020).

Setelah mendapatkan pemahaman media sosial Instagram melalui pengabdian yang dilakukan, mitra dampingan dengan antusias menerapkan strategi post sebanyak 2 kali sehari seperti pada tabel 2. Untuk jam post yang disarankan kepada mitra seperti yang dapat dilihat pada Tabel 2 .

Tabel 2. Tabel jam post

\begin{tabular}{|c|l|l|}
\hline No & Post harian & Jam post \\
\hline 1 & Post pertama & $12.00-13.00$ \\
\hline 2 & Post kedua & $20.00-21.00$ \\
\hline
\end{tabular}

Minimal jumlah post yang dilakukan perhari adalah sebanyak dua kali post. dan jam post dipilih saat jam istirahat yang memungkinkan banyaknya pengguna mengakses media sosial Instagram. 
Berikut gambar 7 menunjukkan data jam post yang dilakukan oleh mitra per minggu dan jam post yang dilakukan.

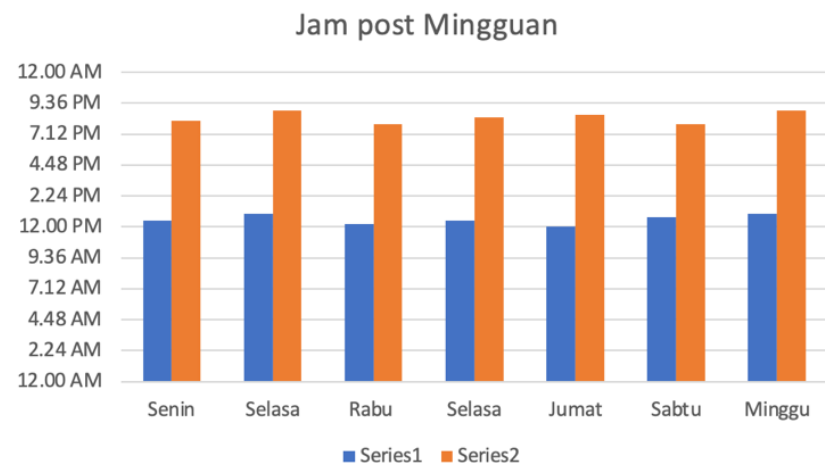

Gambar 7. Jam Post Selama Satu Minggu Yang Dilakukan Mitra

Bagian series 1 merupakan jadwal post jam pertama dan series 2 merupakan post jam kedua di masing-masing hari. Dari data ini menunjukkan mitra dampingan antusias dan berusaha konsisten untuk post konten di tiap hari selama seminggu. Bagian kiri (sumbu y) menunjukkan jam post yang dilakukan mitra dampingan. Di jam pertama mitra dampingan berusaha konsisten untuk post di jam antara 12.00 - 13.00 dan di post kedua, mitra berusaha konsisten post di jam antara $20.00-21.00$. Hal ini menunjukkan semangat serta antusias mitra setelah memahami sosial media Instagram untuk membantu promosi usaha perjalanan wisata mitra.

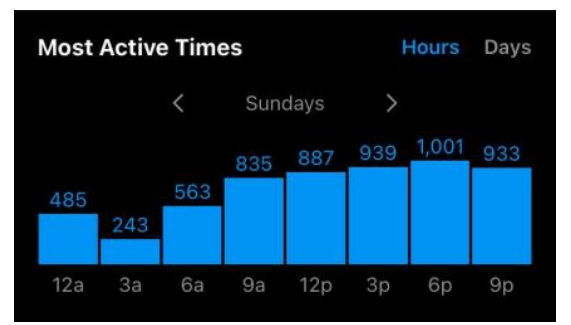

Gambar 8. Waktu Paling Aktif User Instagram yang Diambil dari Insight Akun Mitra

Gambar 8 menunjukkan insight meningkatnya jumlah user aktif di jadwal post yang sudah dilakukan. Di jam 12.00-13.00 terdapat aktif user sebanyak 887 user. Sedangkan di jam 20.00 - 21.00 terdapat jumlah aktif user 933. Dari data ini dapat dilihat post konten di jam tertentu dimanfaatkan untuk menjangkau user pada waktu paling aktif user menggunakan Instagram.

\section{KESIMPULAN}

Berdasarkan hasil kegiatan pengabdian yang telah dilakukan, dapat disimpulkan sebagai berikut.

1. Peserta pengabdian usaha perjalanan wisata UMKM Bali Daily Trip and Tour memiliki antusias yang baik untuk mempelajari tentang promosi digital memanfaatkan sosial media sebagai sarana pemasaran.

2. Peserta mendapatkan informasi melakukan upgrade ke business account dan peserta mendapatkan informasi bagaimana menentukan jadwal posting yang baik. Selain itu peserta juga mendapatkan pemahaman terkait dengan penggunaan fitur insight yang dimiliki oleh Instagram Business.

\section{UCAPAN TERIMA KASIH}

Kegiatan pengabdian masyarakat ini telah selesai dilaksanakan, tentunya kegiatan ini berhasil terlaksana berkat bantuan semua pihat, sehingga ucapan terima kasih kami ucapkan kepada: Bapak Rektor ITB STIKOM Bali yang telah memberikan dukungan penuh terlaksannya kegiatan ini, LPPM ITB STIKOM Bali, mitra pengabdian, serta semua rekan-rekan dosen dan mahasiswa.

\section{DAFTAR PUSTAKA}

Fatanti, M. N. and Suyadnya, I. W. (2015) 'Beyond User Gaze: How Instagram Creates Tourism Destination Brand?', Procedia - Social and Behavioral Sciences. doi: 10.1016/j.sbspro.2015.11.145.

Fauzi, R. (2018) 'Perubahan Budaya Komunikasi pada Pengguna Whatsapp di Era Media Baru', JIKE: Jurnal Ilmu Komunikasi Efek. doi: 10.32534/jike.v1i1.44.

Kirschner, P. A. and De Bruyckere, P. (2017) 'The myths of the digital native and the multitasker', Teaching and Teacher Education. doi: 10.1016/j.tate.2017.06.001.

Latiff, Z. A. and Safiee, N. A. S. (2015) 'New Business Set Up for Branding Strategies on Social Media - Instagram', in Procedia Computer Science. doi: 10.1016/j.procs.2015.12.100.

Leaver, T., Highfield, T., \& Abidin, C. (2020) Instagram: 
Visual social media culture. John Wiley \& Sons.

Meeker, M. (2018) 'Internet Trends Report 2018', I.

Rietveld, R. et al. (2020) 'What You Feel, Is What You Like Influence of Message Appeals on Customer Engagement on Instagram', Journal of Interactive Marketing. doi: 10.1016/j.intmar.2019.06.003.

Suci, Y. R. (2017) 'Perkembangan UMKM (Usaha Mikro Kecil Menengah) di Indonesia’, Jurnal Ilmiah fakultasi Ekonomi. 